\title{
Zinc application improves growth, yield and grain zinc concentration of mung bean (Vigna radiata L.)
}

\section{Aplicação de zinco melhora o crescimento, rendimento e concentração de zinco de grão de feijoeiro (Vigna radiata L.)}

\author{
Mubshar Hussain"; Muhammad Zeeshan Shahid'; Noman Mehboob"; \\ Waqas Ahmed Minhas ${ }^{1}$; Muhammad Akram²
}

\section{Highlights}

Minerals' deficiency is an extensive threat to large portion of global population.

Zinc fertilizers improve yield of mung bean in arid and semi-arid areas.

Zinc was applied as basal, foliar and $50 \%$ basal $+50 \%$ foliar applications.

Zinc $\left(10 \mathrm{~kg} \mathrm{ha}^{-1}\right)$ as basal application was the best option to improve mung bean yield.

\begin{abstract}
Minerals' deficiency, including iodine (I), vitamin A, iron (Fe) and zinc ( $\mathrm{Zn})$ is a widespread threat to mankind. Around 2 billion people (children, women, and people of middle age group) across the globe suffer from mineral deficiencies. The productivity of mung bean is very low in arid and semi-arid regions due to little or no application of fertilizers. Majority of mung bean growing regions of Pakistan have low Zn concentration in soils. This study evaluated the impact of different Zn sources and their application methods on allometry, yield and grain biofortification of mung bean. Mung bean variety "Azri 2006" was used as experimental material. Three different $\mathrm{Zn}$ sources, i.e., zinc sulfate $\left(\mathrm{ZnSO}_{4}\right), \mathrm{Zn}$-EDDHA and $50 \% \mathrm{ZnSO}_{4}+50 \% \mathrm{Zn}$ EDDHA were used. Application method included in the study was basal application, foliar application and $50 \%$ basal $+50 \%$ foliar application. The results indicated that $\mathrm{Zn}$ application improved allometric traits and productivity of mung bean. The $\mathrm{ZnSO}_{4}$ source of $\mathrm{Zn}$ with basal application resulted in the highest chlorophyll contents, leaf area index, number of sympodial and monopodial branches, and number of pods per plant, 1000-seeds weight, biological yield and seed yield as compared to control treatment. In conclusion, $10 \mathrm{~kg} \mathrm{ha}^{-1} \mathrm{Zn}$ application as basal application method seemed a viable option to improve mung bean productivity along with higher grain Zn biofortification.
\end{abstract}

Key words: Mung bean. Optimization. $\mathrm{ZnSO}_{4}$. Zn-EDDHA. Basal application. Foliar application.

1 Department of Agronomy, Bahauddin Zakariya University, Multan, Pakistan. E-mail: mubashiragr@gmail.com; raoshani103@gmail.com; shaweezadil@gmail.com; waqas.minhas05@gmail.com

2 Assistant Professor, Department of Environmental Sciences, COMSATS University Islamabad, Vehari Campus Pakistan. E-mail: akramcp@gmail.com

* Author for correspondence

Received: Mar. 03, 2020 - Approved: Dec. 29, 2020 


\section{Resumo}

Mais de 2 bilhões de pessoas em todo o mundo, incluindo mulheres, crianças e pessoas de meia-idade, sofrem de deficiências de vitaminas e minerais; principalmente iodo, ferro, vitamina A e zinco (Zn). A produtividade do feijoeiro mungo é muito baixa em solos áridos e semi-áridos com pouca ou nenhuma aplicação de fertilizantes. A maioria das regiões do Paquistão tem baixos teores de zinco (Zn). A variedade ung "Azri 2006" foi semeada sob Zn (10 kg ha-1) com diferentes fontes ( $\mathrm{ZnSO}_{4^{\prime}} \mathrm{Zn}$ EDDHA e 50\% $\mathrm{ZnSO}_{4}+$ $50 \%$ Zn EDDHA). O Zn foi aplicado como aplicação a lanço, aplicação foliar e aplicação foliar 50\% basal + $50 \%$. O resultado mostrou que o feijoeiro-mungo apresentou melhor desempenho pela aplicação de zinco em relação a características alométricas e produtividade. $\mathrm{Zn}$ como $\mathrm{ZnSO}_{4} \mathrm{com}$ aplicação basal resultou em teores máximos de clorofila, índice de área foliar, ramos simpodial e monopodial, número de vagens por planta, peso de 1000 sementes, rendimento biológico e produtividade de sementes em relação ao controle. Em conclusão, a aplicação de Zn a $10 \mathrm{~kg} \mathrm{ha}^{-1}$ aplciado a lanço mostrou ser uma opção viável para melhorar a produtividade juntamente com maior biofortificação de Zn de grãos.

Palavras-chave: Feijão-mungo. Otimização. $\mathrm{ZnSO}_{4}$. Zn EDDHA. Aplicação em cobertura. Aplicação foliar.

\section{Introduction}

Pulses are important crops in Pakistan agriculture due to their high protein contents. Pulses are a cheap source of proteins in the country; therefore, large portion of country's population relies on pulses to meet their protein needs (Usman, Hassan, \& Ahmad, 2007). Mung bean (Vigna radiata L.) is an important pulse crop belongs to Fabaceae family. It is rich in proteins, minerals, and vitamins with high digestibility (Sarwar, Sadiq, Saleem, \& Abbas, 2004). Regarding nutritional quality, mung bean contains $60-65 \%$ carbohydrates, $22-28 \%$ protein, $3.5-4.5 \%$ fiber and $1-1.5 \%$ fat (Zaid, Khalil, \& Khan, 2012). Nonetheless, inclusion of mung bean in existing cropping systems is highly beneficial to improve soil fertility because of its biological nitrogen fixation potential.

Zinc (Zn) nutrition plays a vital role in crop production and important for getting higher crop yields (Arif, Ali, Khan, Jan, \& Akbar, 2006; Haider, Hussain, \& Farooq, 2019). The
Zn plays key roles in chlorophyll synthesis, pollination and fertilization process, and seed germination (Cakmak, 2008; Souza, Moraes, \& Moreira, 2019). Zinc application improves cell membrane integrity, especially of root cells along with suppressing the free radical damage to cells under stressful environments (Cakmak, 2000). It also enhances plant resistance against disease causing pathogens. Furthermore, $\mathrm{Zn}$ mediates changes in plant physiology and anatomy for the development of resistance against pests and diseases.

A major portion of world's total cultivated land ( 30\%) is Zn-deficit (Khourgami \& Fard, 2012). Furthermore, Zn deficiency is more dominant in the soils of Indo-Gagnetic plains, since $\sim 50-70 \%$ soils in these plains are Zn-deficit (Alloway, 2008; Maqsood et al., 2015). However, nutrients' deficiency including Zn could be improved through various nutrient/ fertilizer application practices (Ali et al., 2008; Haider, Farooq, Nawaz, \& Hussain, 2018a).

The production of mung bean has been static during the last decade in Pakistan. 
The main reasons behind low production are no or low application of macro and micronutrients, particularly Zn (Imran et al., 2015; Haider, Hussain, Farooq, \& Nawaz, 2018b). The application of $\mathrm{Zn}$ has been found to improved number of seeds per plant, which ultimately contributed to higher productivity of mung bean (Rahman, Adan, Chowdhury, Ali, \& Mahabub, 2015; Haider et al., 2018b). The Zn can be applied via soil, seed, and foliage to improve the productivity of arable crops grown in Zn-deficit soils (Khan, Hassan, \& Maitlo, 2006; Haider et al., 2018a, 2019). Zinc sulphate $\left(\mathrm{ZnSO}_{4}\right)$ is the leading $\mathrm{Zn}$ fertilizer used worldwide, which contains $\mathrm{Zn}$ along with sulfur (Aye, 2011).

Around 2 billion people, including women, middle-aged individuals and children around the world are suffering from minerals and vitamins' deficiency, which primarily includes iodine (I), vitamin A, iron (Fe) and $Z n$. Low or no application of $\mathrm{Zn}$ not only lower the yield of crops including mung bean, but also results in low grain-Zn concentration (Cakmak, 2009; Haider et al., 2019).

Biofortification is a recent agronomic and breeding approach, which enhances nutritional quality of the economic parts of the plants (Dwivedi et al., 2012). Micronutrients can be applied to plants by different methods, including seed treatment, foliar application, and soil amendment (Johnson, Lauren, Welch, \& Duxbury, 2005). Micronutrients' application, i.e., foliar application of magnesium (Mg), manganese (Mn), Fe and $\mathrm{Zn}$ significantly enhanced mung bean growth and yield-related parameters (Kassab, 2005; Haider et al., 2018b). However, soil Zn application is more effective than other application methods. Soil applied $\mathrm{Zn}$ increases grain yield because $\mathrm{Zn}$ remains available throughout growth period, whereas foliar application of $\mathrm{Zn}$ enhances grain Zn contents (Ehsanullah, Randhawa,, Anjum, Nadeem, \& Naeem, 2015). Zinc application improved wheat (Triticum aestivum L.) productivity and Zn concentration in leaves, straw and grain (Khan et al., 2006).

Although improvement in yield and grain $\mathrm{Zn}$ concentration of mung bean with different $\mathrm{Zn}$ application methods is reported, information about the interactive effect of different $\mathrm{Zn}$ sources and $\mathrm{Zn}$ application methods is not available. Therefore, the objective of the study was to evaluate the impact of interactive effect of different $\mathrm{Zn}$ sources $\left(\mathrm{ZnSO}_{4}, \mathrm{Zn}\right.$ EDDHA and $50 \% \mathrm{ZnSO}_{4}+$ $50 \% \mathrm{Zn}$ EDDHA) and Zn application methods (foliar and basal and combination of foliar and basal) on yield and grain Zn contents in mung bean.

\section{Materials and Methods}

\section{Study site}

This study was conducted during spring season, 2017 at Agronomy Research Farm, Bahauddin Zakariya University Multan, Pakistan. Soil samples $(0-25 \mathrm{~cm})$ were collected and tested to record the pre-experimental fertility status of the soil. The experimental soil was clay-loam in texture having $\mathrm{pH} 8.2$, electrical conductivity $3.7 \mathrm{dS} \mathrm{m}^{-1}$ and contained $0.59 \%$ organic matter. The available nitrogen, phosphorous and potassium were $0.026 \%$, $6.40 \mathrm{mg} \mathrm{kg}^{-1}$ and $220 \mathrm{mg} \mathrm{kg}^{-1}$, respectively. Moreover, the soil contained $0.65 \mathrm{mg} \mathrm{kg}^{-1} \mathrm{Zn}$. Meteorological data during the crop growing season are given in Table 1. 
Table 1

Meteorological data during the crop growth cycle

\begin{tabular}{cccc|} 
Months & $\begin{array}{c}\text { Monthly mean } \\
\text { temperature }\left({ }^{\circ} \mathrm{C}\right)\end{array}$ & $\begin{array}{c}\text { Monthly mean relative } \\
\text { humidity }(\%)\end{array}$ & $\begin{array}{c}\text { Total rainfall } \\
(\mathrm{mm})\end{array}$ \\
\hline March & 21.8 & 68.4 & 0.0 \\
April & 30.0 & 53.5 & 5.3 \\
May & 34.0 & 63.1 & 0.1 \\
June & 33.1 & 74.9 & 45.6 \\
\hline
\end{tabular}

Source: Weather Station, Department of Agricultural Engineering, Bahuddin Zakariya University, Multan.

\section{Experimental details}

Seeds of mung bean variety "Azri 2006" were collected from Arid Zone Research Institute (AZRI), Bahawalpur, Pakistan and used in the experiments. Zinc was applied using two different experiment, i.e., $\mathrm{ZnSO}_{4}, \mathrm{Zn}-\mathrm{EDDHA}$ and their combination, i.e., $50 \% \mathrm{ZnSO}_{4}+50 \%$ $\mathrm{Zn}-\mathrm{EDDHA}$. The $\mathrm{Zn}$ was applied either foliar or basal, or combination of $50 \%$ foliar $+50 \%$ basal application. There was no $\mathrm{Zn}$ applied in the control treatment of the study. For basal application, $10 \mathrm{~kg} \mathrm{Zn} \mathrm{ha-1} \mathrm{(Haider} \mathrm{et} \mathrm{al.,} \mathrm{2018b)}$ was applied on the soil surface before crop sowing and mixed in the soil with tillage. In case of foliar application, $1 \% \mathrm{Zn}$ solution was sprayed during reproductive phase of the crop (Haider et al., 2018a). In case of basal application and foliar application combination, $50 \%$ of basal application dose (i.e., $5 \mathrm{~kg} \mathrm{ha}^{-1}$ ) and $50 \%$ of the foliar application dose (i.e., $0.5 \%$ ) were used. The experiment was laid out in randomized complete block design (RCBD) with factorial arrangements. The $\mathrm{Zn}$ sources were kept in main plots, whereas $\mathrm{Zn}$ application methods were randomized in the sub-plots. The net plot size was $1.8 \mathrm{~m} \times 5 \mathrm{~m}$ with three replications.

\section{Crop husbandry}

Before sowing, pre-soaking (locally called rouni) irrigation was given to field for proper seedbed preparation. When field attained appropriate moisture level, field was ploughed with tractor-drawn cultivator followed by planking.

Crop was fertilized with phosphorus (P) and nitrogen (N) at the rate of $50 \mathrm{~kg}$ and $25 \mathrm{~kg}$ ha ${ }^{-1}$ using di-ammonium phosphate (DAP) and urea, respectively at sowing. To fulfill mung bean water requirement, field was irrigated four times. To maintain optimum plant population, thinning was done at 30 days after sowing (DAS). To reduce weed infestation, hand hoeing was done thrice during the growing season.

\section{Data recording}

\section{Crop allometric traits}

The chlorophyll contents were recorded as SPAD value by SPAD meter. Data regarding crop growth rate (CGR) and leaf area index (LAI) were taken at 20 days interval starting from 35 DAS and terminated at crop maturity. Ten plants were randomly harvested from each 
experimental unit, their leaves were separated, and leaf area was recorded by using leaf area meter (MK2, DT, Delta T Devices, Cambridge UK). Further, LAl was recorded by using the formula devised by Watson (1947). Afterwards, fresh samples were weighed, and oven dried at $70^{\circ} \mathrm{C}$ till constant weight. The CGR was then determined by following Hunt (1978). For maintaining average values for CGR and LAI were calculated, presented, and interpreted.

\section{Morphological and yield-related traits}

Ten randomly selected plants from each experimental unit were used to record average plant height, number of monopodial and sympodial branches, and number of pods per plant. Selected plants were harvested with intensive care and measuring tape was used to measures their height. Total number of monopodial and sympodial branches, and pods from harvested plants were carefully counted and averaged. All plants in each experimental unit were harvested and kept in plots for three days. Afterwards, the plants were tied into bundles and weighed using spring balance to record biological yield. All pods present on the plants were then manually separated, threshed to separate grains and weighed using electric balance to record grain yield. Both grain and biological yields were converted to tones ha-1 using unitary method. Three randomly selected samples of 1000 grains were weighed and averaged to record 1000-grain weight. Harvest index was taken as a ratio of grain to biological yield expressed in percentage.

For the determination of grain $\mathrm{Zn}$ concentration, $0.5 \mathrm{~g}$ finely ground mung bean grains were digested in di-acid and burnt on a hot plate. Afterwards grain Zn concentration was estimated according to Prasad (2006) using atomic absorption spectrophotometer (Model: Perkin Almer, CA, USA).

\section{Statistical analysis}

Collected data were tested for normality by Shapiro-Wilk normality test, which indicated a normal distribution. Therefore, original data was used in statistical analysis. Two-way analysis of variance (ANOVA) was used (Steel, Torrie, \& Dickey, 1997) to test the significance in the data (individual and interactive effects of $\mathrm{Zn}$ sources and $\mathrm{Zn}$ application methods). The means were separated by least significant difference post-hoc test at $5 \%$ probability. All statistical computations were performed on Statistix 8.1 software. Moreover, graphical representation of the data was done using Microsoft Excel Program along with \pm S.E (standard errors of means).

\section{Results and discussion}

Zinc sources, application methods and their interaction had significant effect on chlorophyll contents, leaf area index, plant height and crop growth rate, except the nonsignificant effect of application methods and interaction among sources and methods of $\mathrm{Zn}$ application on crop growth rate (Table 2). Basal application of $\mathrm{Zn}$ using $\mathrm{ZnSO}_{4}$ recorded higher chlorophyll contents, leaf area index, plant height and crop growth rate compared with all other combinations; however, control (no application of $\mathrm{Zn}$ ) performed poor in this regard (Figure 1). 
Table 2

Analysis of variance for growth and yield-related traits of mung bean grown under different zinc sources and their application methods

\begin{tabular}{|c|c|c|c|}
\hline Plant traits & Zn sources $(Z n)$ & Zn application methods (M) & $\mathrm{Zn} \times \mathrm{M}$ \\
\hline Chlorophyll contents & $467.90^{* *}$ & $14.24^{* *}$ & $10.26^{* *}$ \\
\hline Leaf area index & $167.32^{* *}$ & $5.29 *$ & $4.55^{* *}$ \\
\hline Plant height (cm) & $103.22^{* *}$ & $16.98^{* *}$ & $8.45^{* *}$ \\
\hline Crop growth rate $\left(\mathrm{g} \mathrm{m}^{-2}\right.$ day $\left.^{-1}\right)$ & $306.46^{* *}$ & $2.48 N S$ & $2.29 \mathrm{NS}$ \\
\hline Monopodial branches & $31.53^{* *}$ & $11.17^{\star *}$ & $3.89 * *$ \\
\hline Sympodial branches & $0.37 N S$ & $25.59 * *$ & $1.73 \mathrm{NS}$ \\
\hline Number of grains per pod & $341.84^{* *}$ & 2.43NS & $4.45^{* *}$ \\
\hline 1000-grain weight (g) & $903.36^{* *}$ & $3.77^{*}$ & $6.38^{* *}$ \\
\hline Grain yield (t ha $\left.{ }^{-1}\right)$ & $20.05^{* *}$ & $202.83^{* *}$ & $22.77^{* *}$ \\
\hline Biological yield $\left(\mathrm{t} \mathrm{ha}^{-1}\right)$ & $3565.64^{* *}$ & $6.78^{* *}$ & $3.06^{*}$ \\
\hline Harvest index (\%) & $116.02^{* *}$ & $6.39 * *$ & $12.97^{* *}$ \\
\hline Grain zinc concentration (mg/kg) & $5.34^{* *}$ & $0.13 \mathrm{NS}$ & $1.46 \mathrm{NS}$ \\
\hline
\end{tabular}

${ }^{* *}=$ Significant at $1 \% ;{ }^{*}=$ Significant at $5 \% ;$ NS = Non-significant.

The Zn sources, application methods and their interaction had highly significant effect on number of sympodial branches per plant, number of grains per pods and 1000 -grain weigh with the exception of nonsignificant effect for $\mathrm{Zn}$ application methods on number of grains per pod. However, only application methods had significant effect on number of sympodial branches per plant (Table 2).
The $\mathrm{ZnSO}_{4}$ by basal application methods' interaction resulted in the highest improvement of monopodial and sympodial branches per plant, number of grains per pod and 1000-grain weight (Figure 2). Nonetheless, $10 \mathrm{~kg} \mathrm{ha}^{-1}$ basal application of $\mathrm{Zn}$ using $\mathrm{ZnSO}_{4}$ had the highest, whereas control treatment resulted in the lowest number of grains per pod, number of monopodial and sympodial branches per plant and 1000-grain weight (Figure 2). 

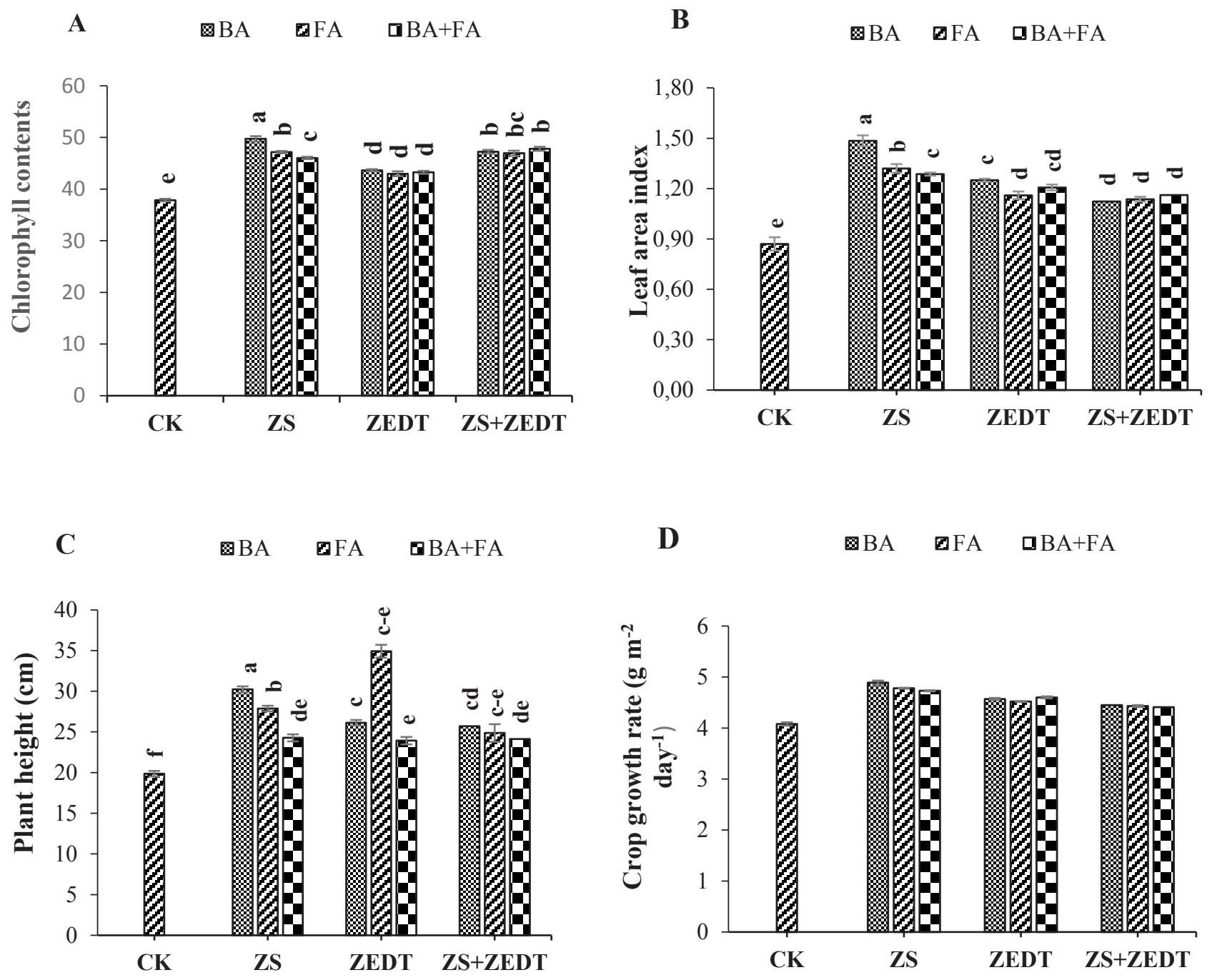

Figure 1. Interactive effects of zinc sources and application methods on chlorophyll contents (SPAD values) (A), leaf area index (B), plant height $(\mathrm{cm})(C)$ and crop growth rate $\left(\mathrm{gm}^{-2}\right.$ day $\left.^{-1}\right)(\mathrm{D})$ of mung bean \pm SE. Means with different letters differ significantly from each other at $p \leq 0.05$.

Here CK = no application of Zn; ZS = Zinc sulphate; ZEDT = Zinc chelate; BA = Basal application; FA = Foliar application 

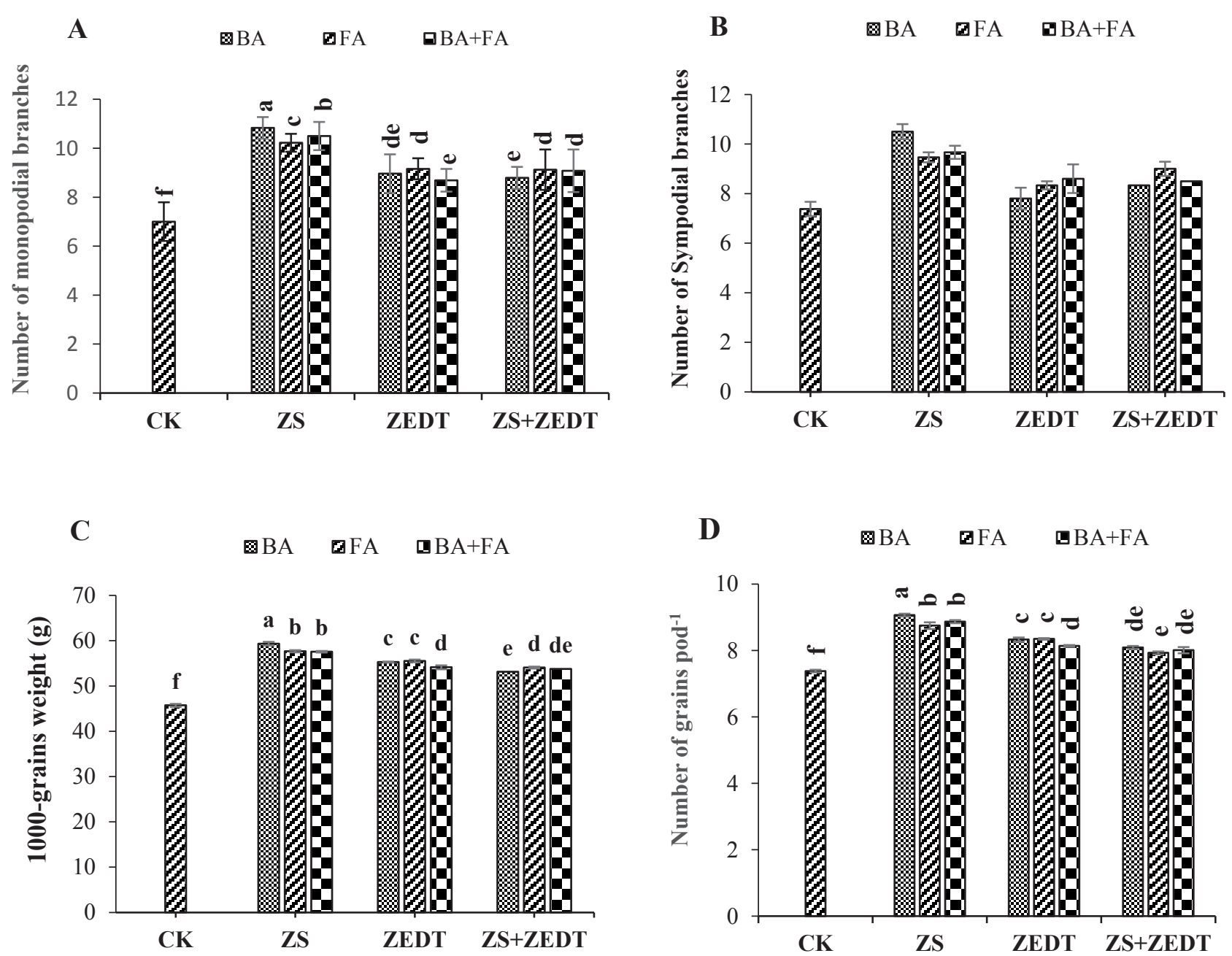

Figure 2. Interactive effect of zinc sources and application methods on number of monopodial branches (A), number of sympodial branches (B), 1000-grain weight $(\mathrm{g})(\mathrm{C})$ and number of grains per pod of mung bean \pm SE. Means with different letters differ significantly from each other at $\mathrm{p} \leq 0.05$.

Here CK = no application of Zn; ZS = Zinc sulphate; ZEDT = Zinc chelate; BA = Basal application; FA = Foliar application.

The individual and interactive effects of $\mathrm{Zn}$ sources and $\mathrm{Zn}$ application methods had highly significant effect on grain and biological yields, and harvest index. However, only $\mathrm{Zn}$ sources had significant on grains $\mathrm{Zn}$ concentrations (Table 2). Application of $\mathrm{ZnSO}_{4}$ as basal application resulted in the highest improvement in grain and biological yields, and harvest index (Figure 3). However, $10 \mathrm{~kg} \mathrm{ha}^{-1}$ basal application of $\mathrm{Zn}$ using $\mathrm{ZnSO}_{4}$ was topperforming, while control (no application of $\mathrm{Zn}$ ) treatment was poor-performing treatment for number of grains, biological yield and harvest index (Figure 3). Zinc application as $\mathrm{ZnSO}_{4}$ resulted in the highest grains $\mathrm{Zn}$ concentration, while control treatment observed the lowest Zn concentration in grains (Figure 3 ). 

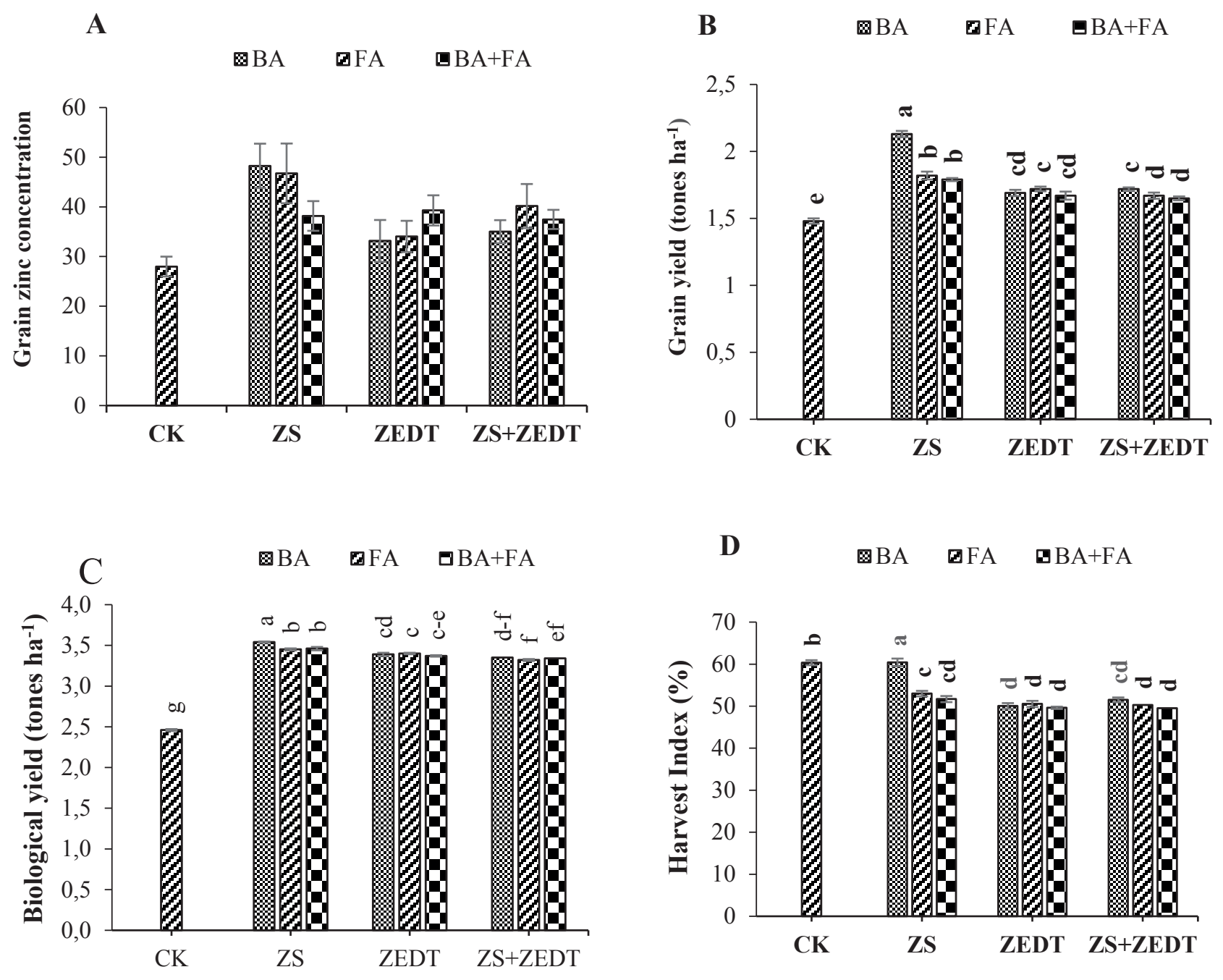

Figure 3. Interactive effects of zinc sources and application methods on grain zinc concentration $(\mathrm{mg} / \mathrm{kg})(\mathrm{A})$, grain yield $\left(\mathrm{t} \mathrm{ha}^{-1}\right)(\mathrm{B})$, biological yield $\left(\mathrm{t} \mathrm{ha}^{-1}\right)(\mathrm{C})$ and harvest index (\%) (D) of mung bean \pm SE. Means with different letters differ significantly from each other at $p \leq 0.05$.

Here CK = no application of Zn; ZS = Zinc sulphate; ZEDT = Zinc chelate; BA = Basal application; FA = Foliar application.

The results of this study unveiled that basal application of $\mathrm{Zn}$ using $\mathrm{ZnSO}_{4}$ at the rate of $10 \mathrm{~kg} \mathrm{ha}^{-1}$ proved the best treatments for improving mung bean performance as indicated through improved morphological parameters, allometric traits, grain yield and grains-Zn biofortification (Figure 1-3). Similar kind of findings was earlier reported for groundnut (Arachis hypogaea) by Prasad et al. (2012).

Zinc is one of the essential micronutrients required for normal plant growth. Zinc is involved in various biochemical processes in plants, including chlorophyll biosynthesis, respiration and photosynthesis, and enzymes' activation (Khan, Umar, Qasim, 
\& Jamil, 2002; Nishizawa, 2005). Zinc plays a dominant role in hormonal (auxin) metabolism; therefore, it stimulates plant nutrition (Penas, Gomez, Frias, \& Vidal-Valverde, 2010). The $\mathrm{Zn}$ helps in cell defense mechanism against reactive oxygen species (ROS). Moreover, it acts like a protector against various chemical compositions of oxidation, including DNA, SH enzyme, chlorophyll, protein and membrane lipids (Cakmak, 2000). Aye (2011) also reported that $\mathrm{ZnSO}_{4}$ is being used across the globe as major source of Sulphur and Zn.

Final productivity of any crop depends on the development of yield components under stressful and benign circumstances. Therefore, improvements in yield-related traits, i.e., number of sympodial and monopodial branches per plant, grains per pod and 1000-grain weight was the key reason of higher yield with Zn application (Figure 2). Zinc application improved chlorophyll contents and leaf area index (Figure 1), which might result higher photosynthesis as evident from higher crop growth rate (Figure 1). Higher chlorophyll contents and leaf area index were noted with $\mathrm{Zn}$ application might be due to more interception of solar radiation and accumulation of more biomass because of higher photosynthesis, which collectively lead to significant improvement in yield-related traits. Recently, Haider et al. (2018a, 2019) also concluded that $\mathrm{Zn}$ application by different methods improved mung bean productivity as observed in this study. In this study basal application of $\mathrm{ZnSO}_{4}$ was most beneficial. Similar findings were also reported by Rahman et al. (2015), who observed that mung bean plants recorded significant improvements in growth and yield-related attributes with
$\mathrm{Zn}$ application. Furthermore, $\mathrm{Zn}$ takes part in auxin production which is mainly responsible for improving cell size and number; therefore, it indirectly enhanced plant growth (Dashadi, Hossein, Radjabi, \& Babainejad, 2013). Usman, Tahir and Majeed (2014) revealed that under $\mathrm{ZnSO}_{4}$ soil amendment, plant observed increase in number of pod-bearing branches, 1000-grain weight, number of grains per pod, harvest index, and biological and grain yields.

Micronutrients are required in minute amount; therefore, soil and foliar application helps in improving crop yields and grain quality (Malakouti, 2008). In this study basal application improved allometric traits and productivity of mung bean, which might be due continuous $\mathrm{Zn}$ availability throughout the life cycle. Moreover, results of the current study also depicted that $\mathrm{Zn}$ application not only improved productivity, but also resulted in higher grainZn concentration. Moreover, applied Zn might also transfer to the economics part, i.e., grains (Figure 3; Haider et al., 2018a; Haider, Hussain, Farooq, \& Nawaz, 2020). Johnson et al. (2005) suggested that soil and foliar applications of $\mathrm{Zn}$ resulted in higher $\mathrm{Zn}$ uptake leading to higher $\mathrm{Zn}$ contents in the grains of chickpea, lentil (Lens culinaris L.), rice (Oryza sativa L.) and wheat compared to no $\mathrm{Zn}$ application. Soil application of $\mathrm{Zn}$ produced a greater number of grains as compare to foliar application because $\mathrm{Zn}$ was available throughout growth period. Earlier studies have indicated $\mathrm{Zn}$ play a major role in enzyme activation; therefore, it is responsible for cell division and elongation, which ultimately enhance plant growth (Nadergoli, Yarnia, \& Khoei, 2011). In another study, Zn application significantly enhanced yield and yield-related traits of mung bean (Ali \& Mahmoud, 2013). 


\section{Conclusion}

In conclusion, Zn application by different methods significantly enhanced grain $\mathrm{Zn}$ concentration and yield-related traits of mung bean. However, Zn application as a basal dose at the rate of $10 \mathrm{~kg} \mathrm{ha}^{-1}$ using $\mathrm{ZnSO}_{4}$ as Zn source improved crop allometry, yield and yield-related traits, and grain $\mathrm{Zn}$ contents. It is therefore recommended to apply $10 \mathrm{~kg}$ $\mathrm{ha}^{-1} \mathrm{Zn}$ using $\mathrm{ZnSO}_{4}$ as $\mathrm{Zn}$ source for higher productivity and grain $\mathrm{Zn}$ concentration of mung bean.

\section{References}

Ali, E. A., \& Mahmoud, A. M. (2013). Effect of foliar spray by different salicylic acid and zinc concentrations on seed yield and yield components of mung bean in sandy soil. Asian Journal of Crop Science, 5(1), 33-40. doi: 10.3923/ajcs.2013.33.40

Ali, S., Khan, A. R., Mairaj, G., Arif, M., Fida, M., \& Bibi, S. (2008). Assessment of different crop nutrient management practices for yield improvement. Australian Journal of Crop Science, 2(3), 150-157.

Alloway, B. J. (2008). Zinc in soils and plant nutrition. Brussels, Belgium; Paris, France: International Zinc Association (IZA) and IFA.

Arif, M., Ali, S., Khan, A., Jan, T., \& Akbar, M. (2006). Influence of farmyard manure application on various wheat cultivars. Sarhad Journal of Agriculture, 22(1), 2729. doi: 10-395/HUT/2011/13-1-137-140

Aye, K. S. (2011). Investigation on the effectiveness of zinc sulphate and biofertilizer on mustard plant. World
Academy of Science, Engineering and Technology, 5(3), 109-111.

Cakmak, I. (2000). Possible roles of zinc in protecting plant cells from damage by reactive oxygen species. New Phytologist, 146(2), 185-205. doi: 10.1046/j.1469-81 37.2000.00630.x

Cakmak, I. (2008). Enrichment of cereal grains with zinc: agronomic or genetic biofortification. Plant and Soil, 302(1-2), 1-17. doi: 10.1007/s11104-007-9466-3

Cakmak, I. (2009). Enrichment of fertilizers with zinc: an excellent investment for humanity and crop production. Journal of Trace Elements in Medicine and Biology, 23(4), 281-289. doi: 10.1016/j.jtemb. 2009.05.002

Dashadi, M., Hossein, A., Radjabi, R., \& Babainejad, T. (2013). Investigation of effect different rates phosphorus and zinc fertilizers on two cultivars lentil (Gachsaran and Flip92-12L) in irrigation complement condition. International Journal of Agriculture and Crop Sciences, $5(1), 1-5$

Dwivedi, S. L., Sahrawat, K. L., Rai, K. N., Blair, M. W., Andersson, M., \& Pfieffer, W. (2012). Nutritionally enhanced staple food crops. Plant Breeding Reviews, 36, 169-291.

Ehsanullah., T. A., Randhawa, M. A., Anjum, A. S., Nadeem, M., \& Naeem, M. (2015). Exploring the role of zinc in maize (Zea mays L.) through soil and foliar application. Universal Journal of Agricultural Research, 3(3), 69-75. doi: 10.13189/ ujar.2015.030301

Haider, M. U., Farooq, M., Nawaz, A., \& Hussain, M. (2018a). Foliage applied zinc ensures better growth, yield and grain 
biofortification of mungbean. International Journal of Agriculture and Biology, 20(12), 2817-2822. doi: 10.17957//JAB/15.0840

Haider, M. U., Hussain, M., \& Farooq, M. (2019). Optimizing zinc seed coating treatments for improving growth, productivity and grain biofortification of mungbean. Soil and Environment, 38(1), 97-102. doi: 10.25252/SE/19/81773

Haider, M. U., Hussain, M., Farooq, M., \& Nawaz, A. (2018b). Soil application of zinc improves the growth, yield and grain zinc biofortification of mungbean. Soil and Environment, 37(2), 123-128. doi: 10.25252/SE/18/71610

Haider, M. U., Hussain, M., Farooq, M., \& Nawaz, A. (2020). Zinc nutrition for improving the productivity and grain biofortification of mungbean. Journal of Soil Science and Plant Nutrition, 20(1), 1321-1335. doi: 10.1007/s42729-020-00215-z

Hunt, R. (1978). Plant growth analysis. London: Edward Arnold.

Imran, H., Khattak, I. I., Rrehman, A. U., Ahamd, F., Zada, H., \& Naveed, S. (2015). Roots nodulation, yield and yield contributing parameters of mungbean cultivars as influenced by different phosphorous level in Swat-Pakistan. Pure and Applied Biology, 4(4), 557-567. doi: 10.19045/ bspab.2015.44015

Johnson, S. E., Lauren, J. G., Welch, R. M., \& Duxbury, J. M. A. (2005). A comparison of the Effects of micronutrient seed priming and soil fertilization on the mineral nutrition of chickpea (Cicer arietinum), lentil (Lens culinaris), rice (Oryza sativa) and wheat (Triticum aestivum L.) in Nepal. Experimental Agriculture, 41(4), 427-448. doi: 10.1017/S0014479705002851
Kassab, O. M. (2005). Soil moisture stress and micronutrients foliar application effects on the growth and yield of mungbean plants. Journal of Agricultural Science, 30, 247-256.

Khan, H., Hassan, Z. U., \& Maitlo, A. A. (2006). Yield and micronutrients content of bread wheat (Triticum aestivum L.) under a multinutrient fertilizer HalTonic. International Journal of Agriculture and Biology, 8(3), 366-370.

Khan, M., Umar, S., Qasim, M., \& Jamil, M. (2002). Effect of different Levels of Zinc on the extractable zinc content of soil and chemical composition of rice. Asian Journal of Plant Science, 1(1), 20-21. doi: 10.3923/ajps.2002.20.21

Khourgami, A., \& Fard, S. R. (2012). The effect of zinc (Zn) spraying and plant density on yield and yield components of green gram. Annals of Agri Bio Research, 3(8), 4172-4178.

Malakouti, M. J. (2008). The effect of micronutrients in ensuring efficient use of macronutrients. Turkish Journal of Agriculture and Forestry, 32(3), 215-220.

Maqsood, M. A., Hussain, S., Aziz, T., Ahmad, M., Naeem, M. A., Ahmad, H. R.,... Hussain, M. (2015). Zinc indexing in wheat grains and associated soils of Southern Punjab. Pakistan Journal of Agricultural Sciences, 52(2), 429-436.

Nadergoli, M. S., Yarnia, M., \& Khoei, F. R. (2011). Effect of zinc and manganese and their application method on yield and yield components of common bean (Phaseolus vulgaris L.). Middle-East Journal of Science and Research, 8(5), 859-865. 
Nishizawa, N. K. (2005). The uptake and translocation of minerals in rice plants. In K. Triyaka, \& K. L. Heong (Eds.), Rice is life: scientific perspectives for the $21^{\text {st }}$ century (pp. 90-93). Manila, Philippines: IRRI.

Penas, E., Gomez, R., Frias, J., \& Vidal-Valverde, C. (2010). Effects of combined treatments of high pressure, temperature and antimicrobial products on germination of mung bean seeds and microbial quality of sprouts. Food Control, 21(1), 82-88. doi: 10.1016/j.foodcont.2009.04.008

Prasad, R. (2006). Zinc in soils and in plant: human and animal nutrition. Indian Journal of Fertiliser, 2(9), 103-119.

Prasad, T. N. V. K. V., Sudhakar, P., Sreenivasulu, Y., Latha, P., Munaswamy, V., Reddy, K. R.,... Pradeep, T. (2012). Effect of nanoscale zinc oxide particles on the germination, growth and yield of peanut. Journal of Plant Nutrition, 35(6), 905-927. doi: 10.1080/01904167.2012.663443

Rahman, M. M., Adan, M. J., Chowdhury, M. S. N., Ali, M. S., \& Mahabub, T. S. (2015). Effect of phosphorus and zinc on the growth and yield of mungbean (BARI mug 6). International Journal of Scientific and Research Publications, 5(2), 1-4.

Sarwar, G., Sadiq, M., Saleem, M., \& Abbas, G. (2004). Selection criteria in F3 and F4 population of mungbean (Vigna radiata L.). Pakistan Journal of Botany, 36(2), 297310.
Souza, J. A., Moraes, L. A. C., \& Moreira, A. (2019). Zinc and amino acids on wheat-soybean intercropping under no-till management. Journal of Plant Nutrition, 42(16), 19922002. doi: 10.1080/01904167.2019.1648 665

Steel, R. G. D., Torrie, J. H., \& Dickey, D. A. (1997). Principles and procedures of statistics: a biometrical approach (3nd ed.). New York: McGraw Hill Co.

Usman, F., Hassan, A., \& Ahmad, A. (2007). Arterial ischemic stroke with protein deficiency in Pakistan. Rawal Medical Journal, 32(2), 205-207.

Usman, M., Tahir, M., \& Majeed, M. A. (2014). Effect of zinc sulphate as soil application and seed treatment on green gram (Vigna radiata L.). Pakistan Journal of Life and Social Science, 12(2), 87-91.

Watson, D. J. (1947). Comparative physiological studies on the growth of field crops: I. variation in net assimilation rate and leaf area between species and varieties, and within and between years. Annals of Botany New Series, 11(1), 41-76. doi: 10.1093/oxfordjournals.aob.a083148

Zaid, U. I., Khalil, I. H., \& Khan, S. (2012). Genetic variability and correlation analysis for yield Components in mungbean (Vigna radiata L.). ARPN Journal of Agriculture and Biological Science, 7(11), 1990-1997. 
